\title{
IMPORTANCE OF RURAL WOMEN AS PART OF THE POPULATION IN TURKEY
}

\author{
Cennet Oğuz ${ }^{1}$
}

Received 27 May 2014; Accepted 30 June 2015

\begin{abstract}
Turkey has a total land potential of 78 million ha with a population about 74 million. About one third of the land is arable, and $26 \%$ of the population has lived in rural areas. The active population, work in the rural area of Turkey, is $14,767,000$ and women have about $51 \%$ of that population. The population of women working in agriculture has shown an increase from year to year. In that regard, importance of women in agricultural activities and rural development is very clear. In agricultural enterprises, the individuals are comprised from $54 \%$ men and $46 \%$ women whose main work is agricultural activities and female economically active population in agriculture is about $55 \%$ in Turkey. The Social Gender Inequality Index, SGII, can be used to make some recommendations for policy makers. SGII is still at a high rate of 0.366 in Turkey. In present paper, some secondary data such as reports and statistical data were analyzed about the contributions of women labor uses in agriculture.
\end{abstract}

Key words: Rural women, labor force, agriculture, agricultural activity.

\section{Introduction}

Traditional agriculture was based on family farms. Families were enterprises at the same time. They had a patriarchal character as a rule, headed by husbandman. Other family members labored according to their possibilities. They were not financially rewarded for their work but they enjoyed the security and protection of the family. The underlying characteristics of traditional family life in peasant society are the authority of the man and the power of the woman (Segalen, 1980).

The situation started to change with the industrialization process. According to Scott and Tilly (1975) most general works on women and the family assume that the history of women's employment, like the history of women's legal and political rights, can be understood as a gradual evolution from a traditional place at home to a modern position in the world of work. Women in industrial countries have achieved education and together with political rights they become economically independent from men. The process in developed countries is widely studied by a number of authors. Concise overview can be found in the paper of Brandth (2002). She identifies three significant discourses in the research literature, namely the discourse of the family farm, the discourse of masculinisation and the discourse of detraditionalisation and diversity. The discourse of the family farm positions men as head of the family farm enterprise;

\footnotetext{
1 Prof. Dr. Cennet OĞUZ University of Selçuk, Faculty of Agriculture Department of Agricultural Economics Konya/Turkey, e-mail: coguz@selcuk.edu.tr
} 
women in the subordinate position of 'farm wives' defined by their dependency, their marriage and family related responsibilities. The second discourse accounts a transformation of gender positions: men and masculinity are losing power and dominance, while women are pictured as taking action and adjusting themselves to late modern life. The "discourse of detraditionalisation and diversity" focuses on the various positions that contemporary women and men have in relation to the farm.

Little and Panelli (2003) highlight discovery of new patterns in gendered lifestyles, experiences, expectations and opportunities in rural areas under the pressure of economic transformation. Shortall (2002) sees the emancipation of rural women in off-farm incomes (which bring more independence) and in the participation of women in rural policy and practice. Recently it seems that the problem of gender equality is shifted from farm women to the problem of rural women in accordance with EU Rural Development Program (Shortall and Bock, 2014). According to Sireni (2015) farm women present themselves, and they are expected to be economically active agents in the post-productivist countryside.

In developing countries women make essential contributions to agriculture. They constitute approximately 43 percent of the agricultural labor force. However, female farmers typically have lower output per unit of land and are much less likely to be active in commercial farming than their male counterparts. These gender differences in land productivity and participation between male and female farmers are due to gender differences in access to inputs, resources, and services (Croppenstedt et al., 2013). The problem is often connected with higher fertility of rural women and resulting poverty (Dixon-Mueller, 2013). The inequality of women can be documented by access of women to ownership of accounts and usage of savings and credit products (Demirgüç-Kunt et al., 2013). Moreover, traditional female role places more demands for informal women activities like care for household, bearing the children, preparing food for the whole family etc. In rural conditions where some infrastructural and technologic conditions (which make the household care easier in urban areas and in developed countries) are missing, women work more hours than men.

The social, cultural and economic development of a society primarily hinges on equality of opportunities that each member of the society. To ensure an effective and balanced growth of society it is essential that all members have equal access to opportunities. In other words, in social works for development, a gender-balanced approach should be adopted. Making up half of the population, women who occupy an essential position within the scope of development programs should be examined individually. Men and women are naturally different so that they have different capabilities. They perform well in different areas of endeavor. Family labor often is used to meet labor requirements. This is especially true in the areas of sustainability agricultural production and rural development. Agricultural enterprises in developing countries are usually run as family businesses and they rely on family labor. Thus, women help their husbands at work and some activities in agriculture.

Illkkaracan (2012) notes that Turkey has one of the widest male-female employment gaps in the world. The prevalence of informal sector employment and absence of paid work-family reconciliation measures magnify these supply-side constraints. Similarly, according to Hes et al. (2013) labor markets of Turkey are characterized by low female labor force participation when compared with the OECD, neighbour states and EU averages. Besides it, the female labor force participation exhibits an unexplained and surprising declining trend in the last decades.

In reality, women comprise $44 \%$ of the agricultural labor force worldwide and $54.73 \%$ of labor in Turkey. The population of women working in agricultural enterprises is growing day by day and most of this growth remains as "unpaid family worker". On the other hand, it is revealed in various studies that needed attention is not given to women in projects and programs carried out within the scope of rural development. Organizations have dedicated to women in agriculture exist in most places in the world, and it is essential that such studies are carried out in Turkey. In the latest study, it was found that it is very important for the Ministry of Agriculture and Livestock to include studies devoted to women and adopting an integrated approach to agriculture. For example, in 9 regions of Turkey, workshops were organized to educate and train rural women in innovative agricultural techniques. This increases their existing potential; create awareness by bringing together partners who work in this field. It also comes out with 
proper solutions, strategies and policies to address this developmental challenge. Inequality in gender in Turkey is still higher as 0.366 by comparison to other developing countries

\section{Analysis of Women Working in Rural Areas of Turkey}

Regardless of the level of development, agriculture plays an important role so special attention is given to agriculture in World Economy. As in Turkey, in a country where roughly $26 \%$ of the population works in agriculture, agriculture is still the main industry with cross-industry relations, safety and assurance of food in terms of employment. Thus, in economic development, it is impossible to assume that agriculture could be ignored. In the agricultural sector, the household women labor which is voluntary and invisible socially remains as the main source of inequality and puts women at a disadvantage compared to men in benefiting from educational opportunities starting from childhood, attaining productive resources, participating in revenue generating workshops, acquiring a profession and having an academic career. The level of support services that socially enables sharing the liability of care on women differs depending on the level of development of countries and the model of Social Welfare State practiced. Women are obliged to either stay at home as housewives or opt for flexible forms of work that could allow combination of work and family responsibilities. Flexible forms of work for women in developing countries implies concentrating on jobs which are usually off the books, deprived of social security as for the developing countries where informal employment is limited in, it implies concentrating on part-time jobs which propose insufficient reforms on social security and low wage rates.

Limitation to particular kinds of jobs, lower wage rates for women than for men, limits to opportunities available to women in rising to higher positions, high probability of unemployment is some of the forms of discrimination women encounter. Raising living standards for people who live in a country plays an essential role in development of a country. In the developed societies in terms of education, culture and economics, productivity and development have observed at high level as compared to other societies. Above all, development of a society in term of social, cultural, and economics is associated with equal opportunities that each member who forms a society has, in other words, it is associated with an approach that ensures gender equality. It is essential for all individuals in a society to have equal access to all opportunities to ensure that all the opportunities are profound for the society to be developed in a balanced way. It is observed that the importance of women is ignored in development plans and programs despite the fact that women make a major contribution to plans and programs.

Women who participate actively in different production processes do not get what they deserve adequately regarding the development opportunities. Majority of the labor potential is provided by employer. Traditional agricultural businesses in the USA and Turkey are the business types based on the labor of the employer and his family. Because it is a family business, the woman helps her husband by most of the works. Women are engaged in agriculture in most of the World. Lessons learned from the development experience indicate that recovery of the status for women is reflected directly in the prosperity of the home. A project in favor of women is significant for an increase in social prosperity as far as it is a necessity in terms of human rights. Since 2002, despite the significant reforms on the living standards of the rural woman, existing indicators have revealed that the living standards of women were poor as compared to the living standards of men.

The key role that women play in agricultural production has been overlooked for many years, and more emphasis is given on the projects aimed at market-oriented production in market economy in development plans and programs. Especially in the year 1983, a discussion has started on the issue of the importance of women in the agricultural sector. In developing countries such as Turkey, the condition, status, accessibility of public service to women especially in rural areas draw attention substantially. In recent years, The Ministry of Agriculture and The Ministry of Public Education were performed projects associated with receiving education and acquiring skills aimed at women in rural areas and organize workshops. Furthermore, many studies were done about roles of women in agricultural production at local and regional levels (Oğuz et al., 2008; Oğuz, 2011; Oğuz et al., 2012). 
The population of economically active working group in rural areas in Turkey is $7,710,000$. Women have the share of $54.73 \%$ of that number. The population of women in agricultural activities has shown an increase year by year. In this point, importance of women in agricultural activities and rural development has increased. The percentage of women in the active agricultural population economically in the world is $42.86 \%$. The contribution of women in agricultural activities was reported as about $20 \%$ in US. The businesses managing by women are small businesses through the world. The population of business managing by women has showed an increase of $1 \%$ in the last decades within the World. They were about $29 \%, 24 \%$, $7 \%$ and $6 \%$ for Austria, Italy, Denmark and Holland, respectively. The share of the agricultural population in Turkey within the total population has gradually decreased as a result of the economic development and rapid urbanization while the share of the agricultural population (village and towns) is $56.2 \%$. This percentage is seen in the Table 1.

\begin{tabular}{|l|c|c|c|c|c|c|c|}
\hline & $\mathbf{1 9 8 0}$ & $\mathbf{1 9 9 0}$ & $\mathbf{2 0 0 0}$ & $\mathbf{2 0 1 0}$ & $\mathbf{2 0 1 1}$ & $\mathbf{2 0 1 2}$ & $\mathbf{2 0 1 3}$ \\
\hline Total Population in Turkey (1000) & $\mathbf{4 3 9 0 6}$ & 53995 & 63174 & $\mathbf{7 2 1 3 8}$ & $\mathbf{7 3 0 5 9}$ & $\mathbf{7 3 9 9 7}$ & 74933 \\
\hline Total Male Population in Turkey (1000) & 21755 & 26637 & 31080 & 35436 & 35884 & 36341 & 36797 \\
\hline $\begin{array}{l}\text { Total Female Population in Turkey } \\
(1000)\end{array}$ & 22150 & 27358 & 32094 & 36701 & 37174 & 37656 & 38136 \\
\hline Female population [\%] & 50.45 & 50.67 & 50.80 & 50.87 & 50.88 & 50.88 & 50.89 \\
\hline Rural population in Turkey (1000) & 24684 & 22028 & 22275 & 21290 & 20818 & 20368 & 19935 \\
\hline Urban population (1000) & 19222 & 31966 & 40900 & 50848 & 52241 & 53629 & 54997 \\
\hline Rural population [\%] & $\mathbf{5 6 . 2 2}$ & $\mathbf{4 0 . 7 9}$ & $\mathbf{3 5 . 2 6}$ & $\mathbf{2 9 . 5 1}$ & $\mathbf{2 8 . 4 9}$ & $\mathbf{2 7 . 5 2}$ & $\mathbf{2 6 . 6 0}$ \\
\hline $\begin{array}{l}\text { Total economically active population } \\
(1000)\end{array}$ & 14418 & 19953 & 21901 & 24457 & 24750 & 25055 & 25362 \\
\hline $\begin{array}{l}\text { Male economically active population } \\
(1000)\end{array}$ & 10587 & 13882 & 15941 & 18010 & 18233 & 18463 & 18695 \\
\hline $\begin{array}{l}\text { Female economically active population } \\
(1000)\end{array}$ & 3831 & 6071 & 5959 & 6447 & 6517 & 6591 & 6667 \\
\hline $\begin{array}{l}\text { Female economically active } \\
\text { population [\%] }\end{array}$ & $\mathbf{2 6 . 5 7}$ & $\mathbf{3 0 . 4 3}$ & $\mathbf{2 7 . 2 1}$ & $\mathbf{2 6 . 3 6}$ & $\mathbf{2 6 . 3 3}$ & $\mathbf{2 6 . 3 1}$ & $\mathbf{2 6 . 2 9}$ \\
\hline $\begin{array}{l}\text { Total economically active population in } \\
\text { Agr (1000) }\end{array}$ & 8147 & 10323 & 9062 & 8005 & 7906 & 7809 & 7710 \\
\hline $\begin{array}{l}\text { Male economically active population in } \\
\text { Agr (1000) }\end{array}$ & $\mathbf{4 7 7 9}$ & 5315 & 4576 & 3731 & 3650 & 3570 & 3490 \\
\hline $\begin{array}{l}\text { Female economically active population } \\
\text { in Agr (1000) }\end{array}$ & 3369 & 5008 & 4486 & 4274 & 4256 & 4239 & 4220 \\
\hline Female eco. Active popul. in Agr. [\%] & $\mathbf{4 1 . 3 5}$ & $\mathbf{4 8 . 5 1}$ & $\mathbf{4 9 . 5 0}$ & $\mathbf{5 3 . 3 9}$ & $\mathbf{5 3 . 8 3}$ & $\mathbf{5 4 . 2 8}$ & $\mathbf{5 4 . 7 3}$ \\
\hline
\end{tabular}

Tab 1. Distribution of Women Working in Rural Areas of Turkey. Reference: www.tüik.gov.tr

The agricultural sector is the largest employer in Turkey. Despite a significant decrease in shares within the national income and the total population, the share of employees in the agricultural sector within the total employment was $31.66 \%$ in the year of 2013 . Compared to the structure of population in the developed countries, it could be stated that this percentage is still high. Migration to urban areas and the rural population occur due to the challenging and impulsive reasons in Turkey. Despite a decrease in shares within the national income and the total population, the share of employees in the agricultural sector within the total employment is $53.6 \%$ in the year of 2013 (Table 2).

Combining work and household for women in rural Turkey, low education and social status, failure in setting up businesses, lack of opportunities for wage based jobs and legal regulations related to jobs such as social security are important issues that need to be addressed (Yıldırak et al., 2003). It is required that the effects of the adverse environmental conditions are reduced and production is boosted by using technological innovations to succeed in agriculture. This could only be possible if sustainable methods in agriculture and permanent solutions are enforced. Areas for work may be improved for women who participate in every stage of production in accordance with technological developments. It may be encouraged that they participate in the activities such as hand crafting, gardening, and greenhouse cultivation. For 
women to live on, it is beneficial that women in rural areas, especially in the mountain villages, get supported through the projects based on development.

\begin{tabular}{|l|c|c|c|c|c|c|}
\hline & \multicolumn{2}{|c|}{ TURKEY } & \multicolumn{2}{c|}{ URBAN } & \multicolumn{2}{c|}{ RURAL } \\
\hline & $\mathbf{2 0 1 2}$ & $\mathbf{2 0 1 3}$ & $\mathbf{2 0 1 2}$ & $\mathbf{2 0 1 3}$ & $\mathbf{2 0 1 2}$ & $\mathbf{2 0 1 3}$ \\
\hline Total Population & 73,604 & 74,457 & 50,397 & 50,885 & 23,207 & 23,572 \\
\hline Age 15 and above & 54,724 & 55,608 & 37,656 & 38,129 & 17,068 & 17,479 \\
\hline Labor (1000) & 27,339 & 28,271 & 18,186 & 18,907 & 9,153 & 9,364 \\
\hline Employment (1000) & 24,821 & 25,524 & 16,167 & 16,736 & 8,653 & 8,788 \\
\hline Unemployed (1000) & 2,518 & 2,747 & 2,018 & 2,171 & 500 & 576 \\
\hline Employment rate (\%) & 50.0 & 50.8 & 48.3 & 49.6 & 53.6 & 53.6 \\
\hline $\begin{array}{l}\text { Percentage of } \\
\text { Employment (\%) }\end{array}$ & 45.4 & 45.9 & 42.9 & 43.9 & 50.7 & 50.3 \\
\hline Unemployment rate (\%) & 9.2 & 9.7 & 11.1 & 11.5 & 5.5 & 6.1 \\
\hline
\end{tabular}

Tab 2. Employment Distribution of Total Population. Reference: www.tüik.gov.tr

\section{Accessibility of Education to Rural Women}

It is expected that the literacy of men and also women in Turkey and education rate reaches to $100 \%$. Education eases access to services for women in addition to increasing employment, social life and decision making process. Providing social mobility and an increase in prosperity level for women who work in rural areas mostly for free or low wages are feasible with realization of sufficient development in education. In the meantime, it is observed that opportunities for access into education especially for girls in rural areas are insufficient. Turkey's agriculture relies on family labor. Knowing the existence of business population in agricultural production is important regarding to establishing the labor of businesses and the evaluation of the labor efficiently. Social and economics specifications of labor, being also a production factor, to be examined is important for studies in terms of improving human factor to generate data.

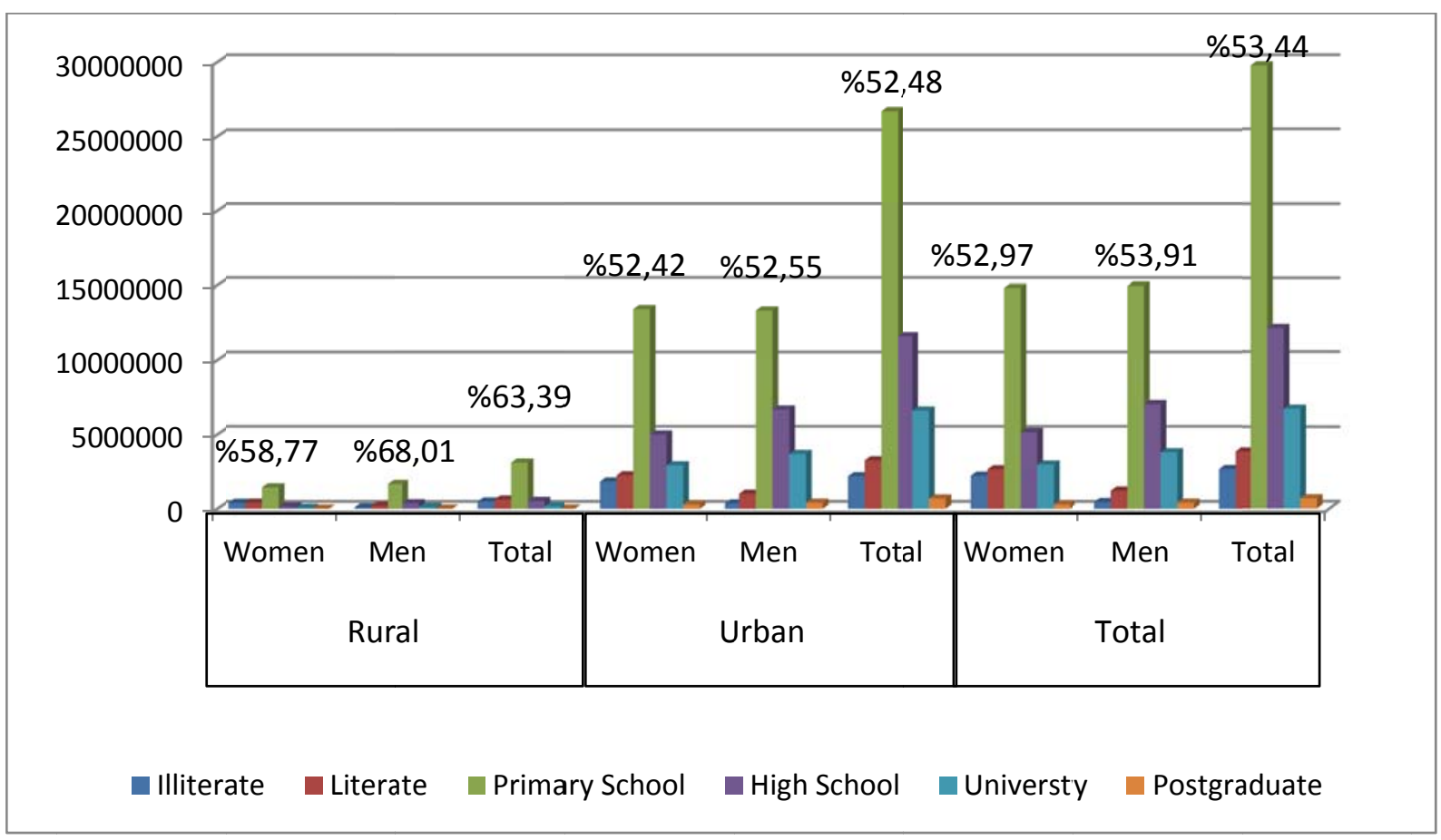

Fig 1. Educational Status of the Population. Reference: www.tüik.gov.tr

Women comprise of $52.97 \%$ of the total population who graduated from all levels of education in Turkey. The $48 \%$ of women who graduated from any education level is the graduates from the Primary School (Fig 1). The percentage of the female students in the institutions of secondary and higher education are lower along with having no big differences in schooling 
rates of female and male students at the Primary School level. Again, regional inequality exists at every stage of education. Financial conditions of families and level of income in rural areas, the need for labour prejudice children's chances for their education to continue after the Primary School Education. However, in every city, participation in these trainings by the rural women and especially girls at the age of 18 and above and obtaining certifications within the educational programs arranged by the Ministry of Public Education, City Halls, the Ministry of Food, Agriculture and Livestock have an important role in their growth and acquiring skills (Table 3). Especially, if agricultural publications are delivered to the women in rural areas on site and on time and trained, women would have an influence on their children and husbands regarding the matter of environment and agriculture.

In Table 3, 48.8\% of the population had non-formal education and training institutions programs. Again, $64.50 \%$ of the young population in the age group of 18-24 participates in the courses and training programs arranged by the training institutions. The $17.50 \%$ of the rural population is in a position where they are the employer. Despite the precautions taken and interventions attempted in Turkey's Agriculture, it is observed that in most regions, agricultural businesses show a tendency to meet primarily their own needs. In other words, these businesses are unable to go through a phase of agricultural market demanded by the market yet. Transition from the phase of subsistence agriculture to market oriented agriculture is not simple because it requires many measures and revisions from production and planning of labor, marketing to assessment. Nevertheless, nearby $90 \%$ of the agricultural businesses in Turkey acts in the way of domestic production in a closed economy.

\begin{tabular}{|c|c|c|c|c|c|c|c|}
\hline & 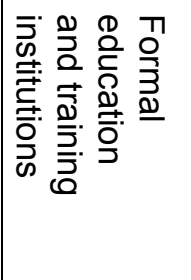 & 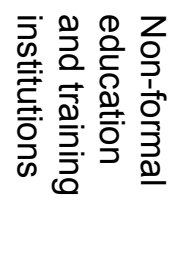 & 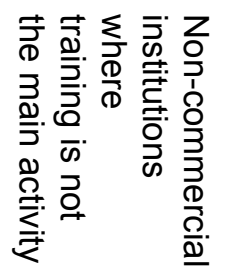 & $\begin{array}{l}\text { m } \\
3 \\
\frac{0}{0} \\
\stackrel{0}{1}\end{array}$ & 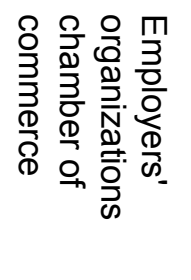 & $\frac{O}{\frac{0}{\sigma}}$ & ○ \\
\hline \multicolumn{8}{|c|}{ Settlement Place } \\
\hline Urban & 10.5 & 41.2 & 4.9 & 27.8 & 2.4 & 13.20 & 100 \\
\hline Rural & 11.4 & 48.8 & 5.0 & 17.5 & 1.8 & 15.50 & 100 \\
\hline \multicolumn{8}{|l|}{ Gender } \\
\hline Man & 9.5 & 34.7 & 6.1 & 34.3 & 3.2 & 12.20 & 100 \\
\hline Women & 12.2 & 53.0 & 3.5 & 14.7 & 1.1 & 15.50 & 100 \\
\hline \multicolumn{8}{|c|}{ Age Group } \\
\hline $18-24$ & 12.0 & 64.5 & 3.7 & 10.3 & 0.6 & 8.90 & 100 \\
\hline $25-34$ & 11.4 & 35.6 & 5.0 & 33.7 & 2.5 & 11.80 & 100 \\
\hline $35-54$ & 9.6 & 33.6 & 5.7 & 31.3 & 3.2 & 16.60 & 100 \\
\hline $55-64$ & 6.5 & 53.2 & 4.2 & 8.4 & 2.8 & 24.90 & 100 \\
\hline $65-+$ & 5.5 & 32.2 & 10.4 & 5.0 & 4.7 & 42.20 & 100 \\
\hline Total & 10.70 & 42.60 & 4.90 & 25.90 & 2.30 & 13.6 & 100 \\
\hline
\end{tabular}

Tab 3. Participation in Non-Formal Education by Settlement Place, Gender, Age Group and Education Providers (2012). Reference: www.tüik.gov.tr

* Trade Unions Individuals

\section{Labor in Agriculture for Turkey}

Lower participation in the labor force arises from the fact that women, especially urbanized women, are largely unemployment. This situation is caused by migration from rural areas to the cities. The population of the rural areas is gradually decreasing the population and the economy of cities is growing in strong. In Turkey where societies are transformed into urbanized societies, women who work in agriculture as employees in the family mostly for free are unable to find any opportunities to participate in the labor market as much as men who migrate into cities even though they might have similar skills and education and migrated the same time to the cities. The reasons for this might be that women do not have the qualifications required by the labor market (taking the responsibility of the family care, 
the limitations brought by the market and the pressure by the family and the environment). For example, differences of urban-rural, it is observed that in urban areas, the participation of women in labor conditions rural areas is higher compared to the participation in urban areas. This situation arises from women working to a great extent as an employee in the family free of charge. As the labor participation rate of women who work in rural areas is examined by years, attention is drawn to a decline due to migration from rural areas to cities. On the other hand, it is seen that labor participation of women who work in cities escalate, however, it is a negligible increase compared to the severe decline in rural areas (BM, 2008). Considering the distribution of the employed population in respect to the sector in which the service is, it is identified that the ones who work in agriculture maintain their importance. With respect to Preliminary temporary results of the survey for the household labor are in the Table 4.

\begin{tabular}{|l|c|c|c|}
\hline Sectors & Total & Woman & Man \\
\hline Agriculture & 24.6 & 39.3 & 18.4 \\
\hline Industry & 26.0 & 14.9 & 30.7 \\
\hline Service (incl. Construction) & 49.4 & 45.8 & 50.9 \\
\hline Total & 100 & 100 & 100 \\
\hline
\end{tabular}

Tab 4. Sectorial Distribution of Employment [\%] (TUIK, 2013). Reference: www.tüik.gov.tr

Women in agriculture perform majority of their production activities as family labor free of charge in small family businesses. Woman in accordance with the specifications of family labor, they either participate in the labor market directly in return for their effort or they get in return when they work in other businesses and hand it over usually to the man who is the head of the family.

\begin{tabular}{|l|c|c|c|c|c|c|}
\hline Forms of Employment & Men & $\%$ & Women & $\%$ & $\begin{array}{c}\text { Total Agricultural } \\
\text { Population }\end{array}$ & $\%$ \\
\hline Unpaid family worker (1000) & 601 & $\mathbf{2 1 . 4 8}$ & 2197 & $\mathbf{7 8 . 5 2}$ & 2798 & 100 \\
\hline $\begin{array}{l}\text { Employer and own account } \\
\text { worker (1000) }\end{array}$ & 2214 & $\mathbf{8 4 . 3 4}$ & 411 & $\mathbf{1 5 . 6 6}$ & 2625 & 100 \\
\hline $\begin{array}{l}\text { Regular employee and casual } \\
\text { employee (1000) }\end{array}$ & 373 & $\mathbf{6 3 . 1 1}$ & 218 & $\mathbf{3 6 . 8 9}$ & 591 & 100 \\
\hline Total (1000) & 3188 & $\mathbf{5 3 . 0 0}$ & 2826 & $\mathbf{4 7 . 0 0}$ & 6014 & 100 \\
\hline
\end{tabular}

Tab 5. Distribution of Employed in Agriculture in Regard to Wage Status. Reference: www.tüik.gov.tr

It is observed that women who work in Turkey as "unpaid family worker". As men comprise the majority of employees, employers and self-employers, high rates of women who become an employee in the family free of charge emphasize how low the significance of women is in rural areas. When the distribution of the wage status for women is viewed (Table 5 ), $78.52 \%$ of the total agricultural population works as unpaid family worker, $15.66 \%$ of it works as an employer, as for $36.89 \%$ of it, they work for wages or daily allowances. According to that, a small portion of the activities in which women participate in for agricultural productions actively is accepted as real work, a majority of the work conducted is considered activities that are obliged in compliance with traditional roles and duties of women. The eye catcher here is that within that data, there are no official data associated with the workers who are commuters.

\section{Analysis of Social Gender Inequality Index (SGII) for Turkey and Some Countries}

Traditional gender roles and socialization process cause some problems. Gender discrimination against women is one of these issues. Gender discrimination against women is a universal issue. In almost every society, women have a lower status compared to men. The United Nations, for this purpose, tries to present the SGII calculations and the development of countries in this topic. As the SGII approaches to zero, women and men earn equal wages in their work lives and as it approaches to one, women or men earn lower wages compared to one another. Magnitude of work is measured with women participation into labor. The SGII is 
designed to reveal to what extent harm is done to the success of national personal development in terms of social gender inequality and to develop some recommendations for policy makers. Turkey's SGII is still at a high rate of 0.366 (table 6 ). In a sense, in all regions, it is in the interest of men that women participate in labor and to get taxed.

\begin{tabular}{|l|c|l|c|}
\hline Country Name & SGII & Country Name & SGII \\
\hline USA & 0.256 & Greece & 0.136 \\
\hline Germany & 0.075 & Italy & 0.094 \\
\hline Spain & 0.103 & The Netherlands & 0.045 \\
\hline France & 0.083 & & \\
\hline United Kingdom & 0.205 & Turkey & $\mathbf{0 . 3 6 6}$ \\
\hline
\end{tabular}

Tab 6. Social Gender Inequality Index (SGII). Reference: www.tüik.gov.tr

Social Gender Inequality Index (SGII) in some selected countries is given in the Table 6 . According to the Table, SGII is extremely low in countries such as Germany, Netherlands, and Italy. In other words, inequality between genders is little if any. The average score of SGII for the World is 0.56 , this score reflects a percentage loss in work conditions and wages due to 56 per cent of social gender inequality (SGII). Regional averages show variances from 32 per cent in countries of the Organization for Economic Co-operation and Development (OECD) to 74 per cent in South Asia. The emerging losses due to SGII at a country level vary from 4.5 per cent in Holland to 85 per cent in the Republic of Yemen. Due to SGIE, the biggest losses occur in Sub Saharan Africa, South Asia, and in Arabic Governments. Women according to the data in Share of Work Based on Social Gender: Perform 2/3rd of the total work in the World, earn $1 / 10$ th of the total income, comprise of $2 / 3 \mathrm{rd}$ of the illiterates within the total population, own 1/10th of private ownership (Gülçubuk et al., 2005).

\section{Conclusion}

Women have been taking big percentage of farm labor, they are not benefiting from rural development aids, so they are the most effectible gender in poverty. For civilization rural development aids must be reached to the women in rural area and women respect must be increased in developing countries. The women working in agriculture commonly are unpaid workers in Turkey since farm owners are men. In this case, rural development aid must be offered to women in order to establish their own business. The business sustainability is depending on the knowledge on the women in rural social and economic situation. There are important problems for the woman to deal with in the rural area of Turkey: e.g. they work in manufacture along with home works, there is low education level and social status, not having possibilities to work for money and the presence of legal regulations deficiencies about working as social security.

Along with the impossibilities to consider employment of rural women independently from macroeconomic employment politics, differences observed between the genders regarding either participation in labor or unemployment rates require this topic to be analyzed in detail.

Empowering women is a top priority in the pre-accession process that is going on between the EU and Turkey. The accession partnership with the EU calls for identification of the challenges women face and specific priorities to promote the role of women in society. A gender-based disadvantageous socio-economic situation is more critical in rural communities. In this sense, studying, analyzing and understanding socio-demographic and socio-economic aspects of rural women's lives is the first step in formulating training and other services for empowering them (Rad et al., 2012).

Sachs and Alston (2010) mention that such contemporary features like globalization of markets, declines in trade subsidies, concentration of agricultural production, increased power of retailers, and consumer demands for healthier and safer food impact on the agriculture including the gender role. 
[1] $6^{\text {th }}$ Periodic Report of Turkey (2008), Ankara, to be presented to CEDAW Committee of the United Nations.

[2] Acker, J. (1992). From Sex Roles to Gendered Institutions. Contemporary Sociology 21(5), 565-569.

[3] Brandth, B. (2003). Gender identity in European family farming: A literature review. Sociologia Ruralis 42(3), 181-200. DOI: 10.1111/1467-9523.00210.

[4] Brown, D. (2000). The misery behind the statistics: Women suffer most. In: Jackson, R, ed., Global Issues 2000/2001. Guilford: McGraw-Hill Inc.

[5] Croppenstedt, A., Goldstein, M. \& Rosas, N. (2013). Gender and agriculture: Inefficiences, segregation and low productivity traps. The World Bank Research Observer 28(1), 79-109. DOI: $10.1093 / \mathrm{wbro} / \mathrm{ks} 024$.

[6] Dayıoğlu, M. (2000). Labour market participation of women in Turkey. In Acre, F. \& GüneşAyata, eds., Gender and Identity Construction: Women of Central Asia, in Caucasus and Turkey. Leiden: Brill Academic Publishers.

[7] Demirbilek, S. (2007). Analysis of Gender Discrimination Socially. Finance, Politics \& Economic Comments 44(511).

[8] Demirgüç-Kunt, A., Klapper, L. \& Singer, D. (2013). Financial inclusion and legal discrimination against women: Evidence from developing countries. World Bank Policy Research Working Papers Nr. 6416. Washington: World Bank.

[9] Dixon-Mueller, R. B. (2013). Rural women at work: Strategies for development in South Asia. London: Routledge.

[10] Gülçubuk, B., Şengül, H. Aluftekin, N. Kızılaslan N. \& Kılıç, M. (2005). In Implementation of Employment Social Security in Agriculture and Rural TMMOB Chamber of Agricultural Engineering VI. Technic Congress.

[11] Gülçubuk, B. (2003). Globalization and the Agricultural Labor Market in Turkey. The $6^{\text {th }}$ Conference of the European Sociological Association. Murcia.

[12] Hes, T., Neradová, A. \& Srnec, K. (2013). Attempt for explanation of declining labor force participation of women in Turkey through test of Under-Participation Trap Hypothesis applied on micro-finance survey data. International Letters of Social and Humanistic Sciences 7, 76-85.

[13] Household Labor Statistics 2013. Ankara: Turkish Statistical Institute.

[14] İlkkaracan, İ. (2012). Why so few women in the labor market in Turkey? Feminist Economies 18(1),1-37. DOI: 10.1080/13545701.2011.649358.

[15] Little, J. \& Panelli, R. (2003). Gender research in rural geography, Gender, Place and Culture 10(3), 281-289. DOI: 10.1080/0966369032000114046.

[16] Oğuz, C., Peker, K. \& Karakayacı, Z. (2007). The Role of Women for Sustainable Agriculture in Turkey. Bulletin of University of Agricultural Sciences and Veterinary Medicine. 64(1-2).

[17] Oğuz, C., Karakayacı, Z. \& Ermetin, Ü. (2008). The Role of Some Socio-Economic Aspect of Turkish Women for Sustainable Agriculture: A Case Study in Konya, Proceedings of the $6^{\text {th }}$ International Symposium Agro Environ Antalya.

[18] Oğuz, C. (2008). The Role of Women in Horticulture; the Case Study of Yaylacık Village in Konya, Turkey. Bulletin of University of Agricultural Sciences and Veterinary Medicine 65(1). Oğuz, C. (2011). The Status of Rural Women in Education and Their Participation in Agriculture", the Case Study of Konya, Turkey. International Technology, Education and Development Conference, Valencia. 
[19] Oğuz, C., Kann, A., Kan, M. \& Ergun, H. (2012). Women's Role in Local Development: A Case of Organic Agriculture in Yaylacık Village, Konya Province, Turkey. Poverty and Protection Conference 2012. Bangkok.

[20] Oğuz, C. \& Kan, A. (2012). Women in Agriculture and Poverty: A Case Study from Highland of Turkey. Poverty and Protection Conference 2012. Bangkok.

[21] Rad, S., Ates, H. Ç., Delioğlan, Ş., Polaköz, S. \& Özçömlekçi, G. (2012). Participation of rural women in sustainable development - demographical and socio-economic determinants. Sustainable Development 20(2), 71-84. DOI: 10.1002/sd.451.

[22] Sachs, C. \& Alston, M. (2010). Global shifts, sedimentations and imaginaries: An introduction to the special issue on women and agriculture. Signs 35(2), 277-287. DOI: $10.1086 / 605618$.

[23] Segalen, M. (1980): Mari et femme dans la société paysanne. Paris: Flammarion.

[24] Scott, J. W. \& Tilly, L. A. (1975). Women's work and the family in nineteenth-century Europe. Comparative Studies in Society and History 17(1), 36-64. DOI: $10.1017 / S 0010417500007635$.

[25] Shortall, S. (2002). Gendered agricultural and rural restructuring: A case study of Northern Ireland. Sociologia Ruralis 42(2), 160-175. DOI: 10.1111/1467-9523.00208.

[26] Shortall, S. \& Bock, B. (2014). Introduction: Rural women in Europe: The impact of place and culture on gender mainstreaming the Europe Rural Development Program. Gender, Place and Culture 22(5), 662-669. DOI: 10.1080/0966369X.2014.917819.

[27] Sireni, M. (2015). Reinventing rural femininities in the post-productivist Finnish countryside. European Countryside 7(1), 42-56. DOI: 10.1515/euco-2015-0003.

[28] Üçeçam Karagel, D. \& Karagel, H. (2009). Women Labor in Rural Areas of (1990-2000). eJournal of New World Sciences Academy 4(3).

[29] Yıldırak, N., Gülçubuk, B. Gün, S. Olhan \& E. Kılıç, M. (2003).Türkiye'de Gezici ve Geçici Kadın Tarım İşçilerinin Çalışma ve Yaşam Koşulları ve Sorunları. Tarım-İş Sendikası Yayınları, Ankara. 